\title{
Detection of pain with neuropathic characteristics in patients with diabetes mellitus assisted in primary care units
}

\author{
Detecção de dor com características neuropáticas em pacientes com diabetes mellitus \\ atendidos na atenção básica
}

Francisca Lidiane Ximenes da Silva Aguiar ${ }^{1}$, Luciana Fernandes Pastana Ramos², Cléa Nazaré Carneiro Bichara ${ }^{3}$

DOI 10.5935/2595-0118.20180005

\section{ABSTRACT}

BACKGROUND AND OBJECTIVES: There is a lack of epidemiological data on neuropathic pain in Brazil. Thus, the present study aimed to detect the presence of pain with neuropathic characteristics in people with diabetes mellitus, assisted by the Hiperdia program in Santarém-Pará.

METHODS: A cross-sectional study was carried out between April and November of 2016 in seven Primary Care Units of Santarém. Patients with types 1 and 2 diabetes mellitus enrolled in the Hiperdia program, who answered a clinical and sociodemographic questionnaire were included. All those who reported pain responded the Douleur Neuropathique 4 questions and the visual analog pain scale. Data were tabulated and statistically analyzed using the software Bioestat 5.0.

RESULTS: The sample consisted of 129 patients, all of whom with type 2 diabetes mellitus. Of these, 67 (51.9\%) reported pain. Of these, $34.1 \%$ were detected with pain of neuropathic characteristics, with a predominance of pain in lower limbs and moderate intensity. The most reported symptoms were: tingling, pinching/needling and numbness.

CONCLUSION: An expressive prevalence of people with neuropathic pain was obtained through the application of the Douleur Neuropathique 4 questions questionnaire, which proved to be an effective and easily applied tool. It is suggested that the neuropathic pain should be identified in the primary care unit and that studies with greater population coverage be performed in Santarém-Pará and in the Northern region, due to the scarcity of data in Brazil.

Keywords: Diabetes mellitus, Pain, Primary care.

1. Universidade Federal do Pará, Programa de Pós-Graduaçâo em Saúde na Amazônia, Belém, PA, Brasil.

2. Universidade Federal do Oeste do Pará, Instituto de Saúde Coletiva, Santarém, PA, Brasil. 3. Universidade do Estado do Pará, Centro de Ciências Biológicas e da Saúde, Belém, PA, Brasil.

Submitted in May 06, 2017.

Accepted for publication in January 08, 2018.

Conflict of interests: none - Sponsoring sources: none.

Correspondence to:

Francisca Lidiane Ximenes da Silva Aguiar

Avenida Magalhães Barata, 790

68030-700 Santarém, PA, Brasil.

E-mail: lidiane_x_aguiar@hotmail.com

(C) Sociedade Brasileira para o Estudo da Dor

\section{RESUMO}

JUSTIFICATIVA E OBJETIVOS: Há uma carência de dados epidemiológicos sobre dor neuropática no Brasil. Assim, o presente estudo teve por objetivo detectar a presença de dor com características neuropáticas em pessoas com diabetes mellitus, atendidos pelo programa Hiperdia, em Santarém-Pará.

MÉTODOS: Estudo transversal, realizado no período de abril a novembro de 2016, em sete Unidades Básicas de Saúde de Santarém. Foram incluídos pacientes com diabetes mellitus tipos 1 e 2, cadastrados no programa Hiperdia, que responderam a um questionário clínico e sociodemográfico. Todos que relataram dor responderam aos questionários Douleur Neuropathique 4 questions e a escala analógica visual. Os dados foram tabelados e analisados estatisticamente através do software Bioestat 5.0 .

RESULTADOS: A amostra foi composta por 129 pacientes, os quais todos possuíam diabetes mellitus tipo 2. Dentre eles, 67 $(51,9 \%)$ referiram dor. Desses, 34,1\% foram detectados com dor de características neuropáticas, com seu predomínio nos membros inferiores e de intensidade moderada. Os sintomas mais relatados foram formigamento, alfinetada/agulhada e adormecimento.

CONCLUSÃO: Obteve-se uma prevalência expressiva de pessoas com dor de características neuropáticas, por meio da aplicação do questionário Douleur Neuropathique 4 questions, que demonstrou ser um instrumento eficaz e de fácil aplicação. Sugere-se que seja feita a identificação da dor neuropática na atenção básica e que sejam realizados estudos de maior abrangência populacional em Santarém-Pará e na região norte, em razão da escassez de dados no Brasil.

Descritores: Atenção básica, Diabetes mellitus, Dor.

\section{INTRODUCTION}

Epidemiological data on the frequency and consequences of neuropathic pain (NP) in patients with diabetes mellitus (DM) is scarce. Studies on this subject are important drivers to improve the treatment of these patients. NP is defined as a chronic pain caused by injury or illness, that involves the somatosensory system $^{1}$. It is considered to be more serious than other types of pain. It is clinically characterized as continuous pain, lacerating, of moderate to severe intensity, with a pricking sensation, the presence of tingling, numbness, and burning. It is preferentially located in the extremities, symmetrically and bilateral, with changes on local sensitivity ${ }^{2}$. 
In addition to its extremely unpleasant symptoms, NP is often associated with anxiety disorder, depression, sleep disorders and sexual dysfunction, which leads to significant decrease in the quality of life and functionality, as well as contributing to social isolation and generating high costs to health services due to disability and absence from work ${ }^{3}$.

Amongst the main causes of NP is diabetic peripheral neuropathy ${ }^{4}$, and it is estimated that at least $10 \%$ of people with DM type 1 (DM1) and 20\% of the people with DM type 2 (DM2) have severe pain ${ }^{2}$, which is of concern since, according to the International Diabetes Federation ${ }^{5}$ it is expected that the number of diabetic people goes up from 387 million recorded until 2014 to 592 million until 2035.

NP pathogenesis in diabetics is not yet fully known and may be related to prolonged hyperglycemia, which leads to the accumulation of toxic substances derived from glucose in body tissues $^{6}$. When the neurological damage occurs, the transmission and perception of painful stimulus in the spinal cord change, modifying nerve conduction and its control, both in the ascendant and descendant pathways, with the consequent increase in the spinal sensory neuron excitability ${ }^{7}$.

The diagnosis of NP is complex, since it is a subjective assessment, difficult to be described and measured, with no consensus yet on the diagnosis of this type of pain ${ }^{1}$. However, it is believed that for a proper assessment, it should be considered the clinical history of the patient, the physical examination with quantitative sensitivity tests, and the use of instruments specific for $\mathrm{NP}^{8}$.

Besides these diagnosis methods, it is extremely important to carry laboratory and image tests, essential to differentiate from other types of pain, in order to have a possible, probable or definitive NP diagnosis ${ }^{9}$, which classification was developed for clinical and investigation purposes to obtain a trustworthy diagnosis ${ }^{1}$.

The International Association for the Study of Pain (IASP) suggests the use of some instruments to detect PN, such as the NP questionnaire in four questions, known as Douleur Neuropathique 4 questions (DN4); the Pain ID; the Leeds Assessment of Neuropathic Symptoms and Signs (LANSS); the questionnaire for pain detention, PainDETECT; and the Neuropathic Pain questionnaire ${ }^{4}$.

It is worth mentioning that it is usually through the primary care unit that people with diabetes enter the Unified Health System (SUS), responsible for the care of all the users with quality and resolvability ${ }^{10}$. Given the breadth and capacity of the primary care, it is important that the detention of pain with neuropathic characteristics occurs in the primary care unit since it is a condition of highly disabling degree that requires distinct treatment, that can be provided by the primary care physician ${ }^{11}$.

Several programs were created to improve primary care services such as the Family Health Strategy (ESF in Portuguese), responsible for the reorganization of the healthcare model, with the creation of multi-professional teams ${ }^{12}$, the Family Health Support Center (NASF in Portuguese), that gather professionals of several specialties to work with the family health and primary care teams ${ }^{13}$. The Hypertensive and Diabetics Record and Fol- low-up System (HIPERDIA), responsible for tracking patients with diabetes and hypertension was also created and became a fundamental instrument to know the users, map the risks, prevent and minimize the complications of these diseases ${ }^{14}$.

Therefore, the Department of Health is fostering new studies on NP in order to meet the demand for epidemiological data and studies about pain management ${ }^{15}$. In this sense, the present study aimed to detect the presence of pain with neuropathic characteristics in people with DM, assisted by the Hiperdia program, in Santarém-Pará.

\section{METHODS}

A prospective cohort cross-sectional study was carried out from April to November 2016, in seven Primary Care Units (UBS in Portuguese) of the district Grande Área da Aldeia, in SantarémPará. Patients enrolled in the population of this study fulfilled the following inclusion criteria: (a) to have DM1 and 2; (b) of both the gender; (c) older than 18 years; (d) registered in the Hiperdia program of the UBS of the district of the Grande Área da Aldeia; (e) were present at the data collection moment and (f) signed the Free and Informed Consent Form (FICT). Patients who did not meet the inclusion pre-requirements were excluded, the ones who did not regularly attend the Hiperdia meetings (at least 3 meetings in last the 6 months) and those who did not have time to participate in the assessment.

Patients were approached randomly and individually by one of the researchers, while waiting for the distribution of drugs, consultation with a nurse or doctor, in the hall of the UBS where the Hiperdia meetings take place once a month in the morning.

All subjects were informed about the objectives and procedures of the study and invited to participate in the study after signing the FICT, elaborated in accordance with the Resolution 196/1996 of the National Health Council (CNS) ${ }^{16}$, ensuring the bioethics principles (beneficence, non-maleficence, justice and autonomy) throughout all the steps of this study, as well as the guarantee of the confidentiality of the information provided by the participants.

In the city of Santarém, according to City Department of Health, there are 5,100 people with DM diagnosis registered in the Hiperdia, being the great majority with DM2 (4,610 people). The District Grande Área da Aldeia, chosen for this study has 60,859 inhabitants and eight UBS. However, only seven were conducting monthly Hiperdia meetings.

According to the information given by the nurses of each health unit, in the seven UBS surveyed there were 1,389 patients registered with diabetes. However, the data was not updated in terms of the number of deceased and people who no longer attend the meetings. When analyzing the attendance list of the three last months, we had a monthly average of 47 people with DM attending the Hiperdia meetings in the studied Health Units.

For the sample calculation, the parameters used were confidence level of $95 \%$, error of $5 \%$ and expected prevalence of $10 \%$.

Participants were selected by means of simple random sampling. The instruments used in this study were: the clinical and sociode- 
mographic questionnaire, prepared by the researchers of this study; DN4 questionnaire ${ }^{17}$; and the visual analog scale (VAS $)^{18}$. Initially, the clinical and sociodemographic questionnaire was applied to collect information about the Health Unit where the follow-up is carried, age, gender, place of birth, race/color, marital status, education and occupation, clinical diagnosis of DM1 or 2, disease duration, pain complaint, drugs in use, and questions about the site of pain and treatment for the patients who have reported the symptom.

Patients who reported pain answered the DN4 questionnaire, considered an effective tool to detect NP in people with diabetes. It has four questions; the two first include seven sensorial descriptors that characterize NP (burning; painful cold sensation; electric shock; tingling; pricking tugging; numbness and itching). The other two questions relate to the physical examination to assess the indicative signs of neurological injury (hypoesthesia to the touch; hypoesthesia to needle stick and brushing) ${ }^{19}$. Participants answered "yes" or "no" to all items. Each positive answer received a " 1 ", and the negative, " 0 ". The result was obtained by adding the 10 items, and the presence of NP was confirmed with scores $\geq 4{ }^{17}$.

Then, patients were evaluated regarding the intensity of pain by VAS, considering a score from zero to 2 for mild pain, 3 to 7 for moderate pain, and 8 to 10 for severe pain ${ }^{8}$.

The project was approved by the Ethics and Research Committee involving humans (CEP) of the Tropical Medicine Center of the Federal University of Pará, with number 2.003.985.

\section{Statistical analysis}

A descriptive analysis of the data was performed, showing the absolute and relative frequency, central trend measures (mean, minimum and maximum) and dispersion measures (standard deviation). The information was recorded in a database created in the Excel 2010 software and imported into Bioestat 5.0, where possible associations between NP and related factors, such as time of the diagnosis of DM, pain intensity, location, and pain treatment were analyzed. The analysis was conducted using the Chi-square test with significance level values of $\mathrm{p} \leq 0.05$ values.

\section{RESULTS}

The sample had 129 patients, with $100 \%$ of patients with DM2. There was a predominance of females (76.7\%); with an average age of $65.1 \pm 9.4$ years; married $(54.3 \%)$ and with incomplete basic education (45\%). The pain scenario was reported by $51.9 \%(n=67)$ of participants, being NP the major type of pain (Table 1 ).

Table 1. Prevalence of pain with neuropathic characteristics in patients with diabetes mellitus included in the Hiperdia program

\begin{tabular}{lcc}
\hline Type of pain & $\mathrm{n}$ & $\%$ \\
\hline Non-neuropathic (DN4<4) & 23 & 34.3 \\
Neuropathic (DN4 $\geq 4)$ & 44 & 65.7 \\
Total & 67 & 100 \\
\hline
\end{tabular}

Assessed by the Douleur Neuropathique 4 questions questionnaire.
The average time of the DM diagnosis was higher in people who reported pain with neuropathic characteristics (10.05 \pm 7.07$)$. People with non-neuropathic characteristics pain had an average of $7.67 \pm 5.48$, and individuals with no pain, $7.55 \pm 6.21$.

The most referred pain location by patients was the feet, both for people with neuropathic characteristics and those with nonneuropathic characteristics, as shown in table 2 .

Table 2. Site of pain among patients with pain with neuropathic and non-neuropathic characteristics

\begin{tabular}{lcccc}
\hline Site of pain & \multicolumn{2}{c}{ Neuropathic pain } & Total & $\mathrm{x}^{2}$ \\
& Yes (\%) & No (\%) & $\mathrm{n}(\%)$ & \\
\hline Hands & $2(4.55)$ & $3(13.04)$ & $5(7.46)$ & $\mathrm{p}=0.1634$ \\
Legs & $3(6.82)$ & $2(8.70)$ & $5(7.46)$ & \\
Feet & $22(50)$ & $16(69.57)$ & $38(56.72)$ & \\
Hands and feet & $10(22.73)$ & $2(8.70)$ & $12(17.91)$ & \\
Legs and feet & $6(13.64)$ & $0(0)$ & $6(8.96)$ & \\
Arms and legs & $1(2.27)$ & $0(0)$ & $1(1.49)$ & \\
Total & $44(100)$ & $23(100)$ & $67(100)$ & \\
\hline
\end{tabular}

Assessed using the clinical and sociodemographic questionnaire elaborated by the author.

According to the data of the DN4 questionnaire (Table 3), patients with NP $(n=44)$ presented a higher number of complaints $(n=279)$ related to soreness, especially in relation to the tingling, pricking/tugging, and numbness.

Table 3. Distribution of the Douleur Neuropathique 4 questions questionnaire items among patients with neuropathic and non-neuropathic pain

\begin{tabular}{lccc}
\hline Sensory descriptors & \multicolumn{2}{c}{ Neuropathic pain } & Total \\
& Yes (\%) & No (\%) & $\mathrm{n}(\%)$ \\
\hline Tingling & $42(15.05)$ & $9(3.33)$ & $51(15.55)$ \\
Pricking/tugging & $41(14.70)$ & $10(3.70)$ & $51(15.55)$ \\
Numbness & $39(13.98)$ & $8(2.96)$ & $47(14.33)$ \\
Electric shock & $32(11.47)$ & $5(1.85)$ & $37(11.28)$ \\
Itching & $17(6.09)$ & $3(1.11)$ & $20(6.10)$ \\
Burning & $25(8.96)$ & $7(2.59)$ & $32(9.76)$ \\
Painful cold sensation & $25(8.96)$ & $2(0.74)$ & $27(8.23)$ \\
Physical sensitivity examination & & & \\
$\quad$ Hypoesthesia to touch & $30(10.75)$ & $4(1.48)$ & $34(10.37)$ \\
$\quad$ Hypoesthesia to pricking & $19(6.81)$ & $1(0.37)$ & $20(6.10)$ \\
$\quad$ Brushing & $9(3.23)$ & $0(0)$ & $9(2.74)$ \\
Total & $279(100)$ & $49(100)$ & $328(100)$ \\
\hline
\end{tabular}

Table 4 shows VAS results with moderate pain intensity being the most frequent. The present study shows that there is no statistically significant difference in the association between NP and intensity of pain.

When asked about any treatment for pain, a great part of the individuals with neuropathic characteristics confirmed the use of conventional painkillers as the pharmacological treatment $(52.27 \%)$, as shown in table 5 . 
Table 4. Distribution of pain intensity in patients with pain with neuropathic and non-neuropathic characteristics

\begin{tabular}{|c|c|c|c|}
\hline \multirow[b]{2}{*}{ Pain intensity } & \multicolumn{2}{|c|}{ Neuropathic pain } & \multirow[b]{2}{*}{$x^{2}$} \\
\hline & Yes (\%) & No (\%) & \\
\hline Mild (0-2) & $9(20.45)$ & $6(26.09)$ & \\
\hline Moderate (3-7) & $19(43.18)$ & $14(60.87)$ & $p=0.1307$ \\
\hline Severe (8-10) & $16(36.36)$ & $3(13.04)$ & \\
\hline Total & $44(100)$ & $23(100)$ & \\
\hline
\end{tabular}

Assessed by the visual analog pain scale.

Table 5. Distribution of patients with pain with neuropathic and non-neuropathic characteristics regarding pain treatment

\begin{tabular}{lcccc}
\hline \multirow{2}{*}{$\begin{array}{l}\text { Pain } \\
\text { treatment }\end{array}$} & \multicolumn{2}{c}{ Neuropathic pain } & \multicolumn{1}{c}{$\begin{array}{l}\text { Total } \\
\mathrm{n}(\%)\end{array}$} & $\mathrm{x}^{2}$ \\
\hline No & $21(47.73)$ & $17(73.91)$ & $38(56.72)$ & $\mathrm{p}=0.0400$ \\
Yes & $23(52.27)$ & $6(26.09)$ & $29(43.28)$ & \\
Total & $44(100)$ & $23(100)$ & $67(100)$ & \\
\hline
\end{tabular}

Assessed using the clinical and sociodemographic questionnaire elaborated by the author.

\section{DISCUSSION}

In this research, the sample was entirely composed of people with DM2. Two similar studies also showed a high prevalence of DM2, one study with $90.4 \%$ of the sample ${ }^{20}$ and the other with $86.3 \%{ }^{21}$. The high frequency observed of type 2 can be explained by the fact that this classification represents, in adults, about 90 to $95 \%$ of all the diagnosed cases $^{22}$.

The result has also revealed that $51.9 \%$ of the sample subjects complained of pain, with a global prevalence of $34.1 \%$ of pain with neuropathic characteristics and $17.8 \%$ non-neuropathic. In a similar study conducted in the United Kingdom with 326 diabetics, $63.8 \%$ reported pain, distributed in $19 \%$ with NP (less than the observed in the results of this survey) and $36.8 \%$ with non-neuropathic pain ${ }^{23}$.

The prevalence of NP observed in this study is similar to the ones conducted in other countries, like in the South Africa ${ }^{24}$ in people with DM1 and 2, also using the DN4 questionnaire, showing a frequency of $30.3 \%$ of NP in a sample of 1,046 people. In the northeast of England, a study with 204 people with DM1 and 2 , in which the LANSS pain scale was applied, the global prevalence of painful diabetic neuropathy was $30.4 \%{ }^{25}$.

On the other hand, the literature shows a lower prevalence of NP compared to this study. In Nigeria, in a study conducted with 250 diabetics, applying the painDETECT questionnaire, showed a prevalence of $21.6 \%{ }^{26}$. Such situation also was observed in studies with the DN4 in Istambul ${ }^{20}$, Turkey, with 1,357 diabetics and the prevalence was $23 \%$. In the city of Tubarão ${ }^{27}$ in Santa Catarina, with 72 people, it was $16.7 \%$; and in Korea $^{28} 14.4 \%$. On the other hand, a study conducted with 2,358 diabetics Chinese, showed a value below what it is seen in the literature, only $7.6 \%{ }^{29}$.

In Saudi Arabia ${ }^{30}$, where 1,039 diabetic patients were evaluated using the DN4, the prevalence of NP was higher than expected (65.3\%), explained by the researchers as a consequence of the poor glycemic control, since hyperglycemia for a prolonged period can cause irreversible tissue damages ${ }^{31}$.

We can observe a wide variety in the prevalence of NP in the world. This is because the epidemiological studies are carried out with different methodologies, sample selection, diagnostic criteria and assessment tools, not to mention the influence of the cultural and sociodemographic diversity ${ }^{8,32}$.

Another important factor observed in the studies on NP is that many researchers carried their research with samples composed of people with the clinical diagnosis of diabetic neuropathy. It is believed that the pain associated with diabetic polyneuropathy is clearly neuropathic, and it is possible to have neuropathy with and without $\mathrm{NP}^{1,33}$, suggesting that there is no relationship between the presence of neuropathy and a higher risk of developing $\mathrm{NP}^{34}$. As observed in a study with diabetic patients, with and without neuropathy, in a sample of 15,692 people, where the NP prevalence was $34 \%{ }^{35}$. In this study, the group without neuropathy was the one that presented the highest frequency of NP.

From this result, the authors highlight the importance to assess the signs and symptoms related to pain in all the patients, and not only in those with confirmed neuropathy, indicating that the painful neuropathic symptoms are neglected by the healthcare services. It is worth mentioning that the current study did not investigate the presence of neuropathy, searching only for pain with neuropathic characteristics in individuals with diabetes, since the NP can occur even in the absence of neuropathy ${ }^{23}$.

In the current study, there was a predominance of females in $76.74 \%$ of the sample, a fact corroborated in other studies with 60 to $70 \%$ of women ${ }^{27,36}$. Other studies, however, reported little difference between gender, but still with a female predominance ${ }^{20,21,24}$. A higher prevalence of men has also been observed in people with diabetes and NP25,37.

Some time ago, women prevalence was expressly higher, explained by the fact that they seek for health services more often than men, getting the diagnosis at an early stage. This scenario is changing with the advance of active search for diabetes, reducing the difference between gender ${ }^{38}$.

The average of age of the sample population was $65.1 \pm 9.4$ years, with little difference between the groups. It is believed that a higher occurrence of NP increases with age ${ }^{35}$. Some authors highlighted the predominance of people above of 60 years of age in the composition of their samples ${ }^{21,25-27,29}$, pointing that senior people have a higher risk to develop NP, since, a great part of the diseases that cause this type of pain has greater incidence with aging ${ }^{39}$.

However, some studies showed the prevalence of NP in people with diabetes with an average age below 60 years $^{20,36}$. This reduction of the age group shows that, although the evidence points to the increased prevalence of diabetes in the elderly ( $\geq 65$ years), there is an increase of the disease in middle-aged adults (35-64 years $)^{40}$, justified by the sedentary lifestyle and bad dietary habits adopted by great part of the population, leading to obesity 5

In terms of educational level, incomplete basic education was more prevalent in the sample, showing significance between the 
groups, as observed in another study with $62 \%{ }^{41}$. These results are in accordance with the Brazilian reality, registered by the Brazilian Institute of Geography and Statistics that the elderly population has up to 4 years of education ${ }^{42}$. This occurrence can be related with the profile of the users who use the services of the ESF, characterized by senior people, of low income and low educational level, that have a poor perception of their health and need more care since they are more susceptible to illness ${ }^{43,44}$.

As for the marital status, more than half of the sample was married $(54.26 \%)$, a fact considered positive because it is believed that the individual inserted in a family environment tends to receive greater support and help during treatment and self-care ${ }^{41}$.

In the present study, the global average of time of the diabetes diagnosis was $8.09 \pm 6.55$ years. People with pain with neuropathic characteristics had a higher average $(10.05 \pm 7.07)$. However, there was no statistical significance between the studied groups, as well as in the research conducted in Korea ${ }^{28}$. However, many authors have reported that the time of the diabetes diagnosis is related to the development of $\mathrm{NP}^{25,27,29,45}$.

The sample was composed of $92.54 \%$ of individuals that reported pain in the lower limbs, the majority in the feet, in both groups. However, there was no association between the site of pain and pain with neuropathic characteristics $(\mathrm{p}=0.1634)$. Usually, pain affects the lower extremities with higher frequency, characterizing the "stocking pattern" 46 .

Concerning the DN4, the item "tingling" was the most reported by those who have reported pain $(15.55 \%)$, together with the symptom "pricking and tugging" with the same percentage. Finally, "numbness" with $14.33 \%$. These three symptoms were also the most frequent among people with pain with non-neuropathic characteristics, with higher ratio observed in those with neuropathic pain.

A similar result was observed in South Africa ${ }^{24}$, where "burning" $(36.5 \%)$ was the most reported complaint, followed by "pricking and tugging" (35.4\%) and "numbness" (31.2\%). These results are in agreement with the literature, pointing tingling, numbness, burning, continuous, lacerate pain with needle stick sensation as clinical manifestations of the $\mathrm{NP}^{2,47}$.

In terms of intensity of pain, it was observed that $36.36 \%$ of the volunteers reported severe pain according to the VAS, while people with pain with non-neuropathic characteristics, only $13.04 \%$. However, there was no significant difference in relation to the intensity among the researched groups $(\mathrm{p}=0,1307)$. French researchers had also observed that the intensity of pain was significantly higher in individuals with NP $(p<0.001)^{37}$. In the current study, moderate pain was more frequent in both groups, corroborating the findings in South Africa, where the majority of the participants $(67.7 \%)$ have also reported moderate pain ${ }^{24}$. The results of these studies are different from other authors who reported sever pain as the most frequent in their samples ${ }^{36}$.

It is known that the clinical manifestations of the NP are presented with intensity from moderate to severe ${ }^{2}$. However, the painful experience varies according to the perception of each individual, and it can be associated with the aspects of each cul- ture, religious beliefs, and even different forms of health percep$\operatorname{tion}^{48}$. A study conducted with Asians showed that this population reported less serious problems when compared with people from Latin America and the Middle East ${ }^{36}$.

All the participants in the present sample reported taking some medication for diabetes, indicating good treatment compliance. However, it is important to remember that although the treatment of diabetes is fundamental to prevent complications and the onset of NP, the control of the underlying disease should not to be the only form to fight the NP since it has an adjuvant action in its treatment ${ }^{49}$. However, when asked about following a pain treatment, $52.27 \%$ of the people with neuropathic pain reported having some type of intervention, while within people with non-neuropathic pain it was only $26.09 \%$, showing association $(0,0400)$. It is believed that this difference among the groups may have occurred due to the extremely unpleasant characteristics of the NP, frequently reported by the patients ${ }^{2}$, that makes them seek treatment.

Likewise, a study showed that the group of patients with diabetic neuropathy and NP was more medicated in comparison with the group with neuropathy, but without pain ${ }^{33}$. Similarly, in a study conducted in Brazil, $72 \%$ of the patients with NP had some type of analgesic treatment, indicating that adults with NP seek for care more than the people who do not have this symptom ${ }^{47}$.

Another possibility would be the high pain intensity observed in patients with neuropathic characteristics in this study, since $36.36 \%$ of the individuals reported severe pain according to the VAS, whereas in patients with non-neuropathic characteristics, only $13.04 \%$.

Although more than half of the sample (52\%) reported pain, we noticed that the only treatment provided in the healthcare units surveyed was the treatment of the underlying disease. When asked about the treatment they were following to alleviate pain, the surveyed patients reported the use of ordinary painkillers associated with muscle relaxants, teas, and massage gels.

In a study conducted in Nigeria ${ }^{26}, 81.5 \%$ used painkillers. However, only $20.5 \%$ were using the ones recommended for NP. In some epidemiologic studies, the majority of the people with NP were using analgesics not suitable for this type of pain, such as nonsteroidal anti-inflammatory drugs and paracetamol ${ }^{21,24}$.

The use of conventional analgesics is ineffective in the treatment of NP, being necessary the administration of proper drugs as antidepressants, anticonvulsants and opioids ${ }^{50}$. Although the World Health Organization has included drugs for the NP in its list of essential drugs, in the majority of the emergent and developing countries, this list model is deficient in terms of efficient drugs for the $\mathrm{NP}^{51}$.

\section{CONCLUSION}

With the results obtained in this study, it is clear the need to identify pain with neuropathic characteristics in the primary care units so that, through an active search, it will be possible to elaborate strategies for the prevention of this type of pain, establishing an adequate intervention and generating epidemiological information to assist the management of pain. 


\section{REFERENCES}

1. Treede RD, Jensen TS, Campbell JN, Cruccu G, Dostrovsky JO, Griffin JW, et al. Neuropathic pain: redefinition and a grading system for clinical and research purposes. Neurology. 2008;70(18):1630-5.

2. Franco LC, Souza LA, Pessoa AP, Pereira LV. Terapias não farmacológicas no alívio da dor neuropática diabética: uma revisão bibliográfica. Acta Paul Enferm. 2011;24(2):284-8.

3. O'Connor AB. Neuropathic pain: quality-of-life impact, costs and cost effectiveness of therapy. Pharmacoeconomics. 2009;27(2):95-112.

4. International Association for the Study of Pain. The 2014-2015 Global Year Against Neuropathic Pain campaign. International Association for the Study of Pain; 2014.

5. International Diabetes Federation. IDF Diabetes Atlas. Bruxelas, Bélgica: International Diabetes Federation; 2014.

6. Aslam A, Singh J, Rajbhandari S. Pathogenesis of painful diabetic neuropathy. Pain Res Treat. 2014;2014:412041.

7. Palladini MC. editor. Diabetes na prática clínica: Dor neuropática, diagnóstico e tratamento [E-Book 2.0]. Sociedade Brasileira de Diabetes; 2014 [acesso em 30 ago 2015]. Disponível em: http://www.diabetes.org.br/ebook/component/k2/item/77-capitulo-14-dor-neuropatica-diagnostico-e-tratamento.

8. Haanpää M, Attal N, Backonja M, Baron R, Bennett M, Bouhassira D, et al. NeuPSIG guidelines on neuropathic pain assessment. Pain. 2011;152(1):14-27.

9. Miranda CC, Seda JL, Pelloso LR. Nova classificação fisiológica das dores: o atual conceito de dor neuropática. Rev Dor. 2016;17(Suppl 1):S2-4.

10. Ministério da Saúde. Secretaria de Atenção à Saúde. Departamento de Atençấo Básica. Política Nacional de Atenção Básica. Brasília; 2012.

11. Haanpää ML, Backonja M, Bennett MI, Bouhassira D, Cruccu G, Hansson PT, et al. Assessment of neuropathic pain in primary care. Am J Med. 2009;122(10 Suppl):S13-21

12. Ministério da Saúde. Departamento de Atençẫo Básica. Atençăo Básica: saúde da família. Brasília; 2011.

13. Ministério da Saúde. Portaria no 2.488, de 21 de outubro de 2011. Aprova a Política Nacional de Atenção Básica, estabelecendo a revisão de diretrizes e normas para a organização da atençâao básica, para a Estratégia Saúde da Família (ESF) e o Programa de Agentes Comunitários de Saúde (PACS). Brasília; 2011.

14. Carvalho Filha FS, Nogueira LT, Viana LM. Hiperdia: adesão e percepção de usuários acompanhados pela Estratégia Saúde da Família. Rev Rene. 2011;12(nº esp):930-6.

15. Ministério da Saúde. Secretaria de Atençăo à Saúde. Portaria no 1083 , de 02 de outubro de 2012. Aprova o Protocolo Clínico e Diretrizes Terapêuticas da Dor Crônica. Brasília; 2012.

16. Conselho Nacional de Saúde (Brasil). Resoluçăo no 196 de 10 de outubro de 1996. Aprova diretrizes e normas regulamentadoras de pesquisa envolvendo seres humanos. Diário Oficial da Uniāo. 10 out 1996.

17. Bouhassira D, Attal N, Alchaar H, Boureau F, Brochet B, Bruxelle et al. Comparison of pain syndromes associated with nervous or somatic lesions and development of a new neuropathic pain diagnostic questionnaire (DN4). Pain. 2005;114(1):29-36.

18. Sousa FA. Dor: o quinto sinal vital. Rev Lat Am Enfermagem. 2002;10(3):446-7

19. Spallone V, Morganti R, D'Amato C, Greco C, Cacciotti L, Marfia GA. Validation of DN4 as a screening tool for neuropathic pain in painful diabetic polyneuropathy. Diabet Med. 2012;29(5):578-85

20. Celik S, Yenidunya G, Temel E, Purisa S, Uzum AK, Gulum N, et al. Utility of DN4 questionnaire in assessment of neuropathic pain and its clinical correlations in Turkish patients with diabetes mellitus. Prim Care Diabetes. 2016;10(4):259-64.

21. Gore M, Brandenburg NA, Hoffman DL, Tai KS, Stacey B. Burden of illness in painful diabetic peripheral neuropathy: the patients' perspectives. J Pain. 2006;7(12):892-900.

22. Centers for Disease Control And Prevention. National Diabetes Statistics Report: Estimates of Diabetes and Its Burden in the United States, 2014. Atlanta, GA: US Department of Health and Human Services; 2014.

23. Davies M, Brophy S, Williams R, Taylor A. The prevalence, severity, and impact of painful diabetic peripheral neuropathy in type 2 diabetes. Diabetes Care. 2006;29(7):1518-22.

24. Jacovides A, Bogoshi M, Distiller LA, Mahgoub EY, Omar MKA, Tarek IU, et al. An epidemiological study to assess the prevalence of diabetic peripheral neuropathic pain among adults with diabetes attending private and institutional outpatient clinics in South Africa. J Int Med Res. 2014;42(4):1018-28.
25. Aslam A, Singh J, Rajbhandari S. Prevalence of painful diabetic neuropathy using the self-completed leeds assessment of neuropathic symptoms and signs questionnaire in a population with diabetes. Can J Diabetes. 2015;39(4):285-95.

26. Ojo OO, Odeniyi IA, Iwuala SO, Oshinaike OO, Okubadejo NU, Fasanmade OA. Frequency of neuropathic pain in type 2 diabetes mellitus at the Lagos University Teaching Hospital: a questionnaire-based outpatient survey. J Clin Sci. 2016;13(2):46-50.

27. Cortez J, Reis C, Cardoso Y, Onofre A, Piovezan AP. Prevalence of neuropathic pain and associated factors in diabetes mellitus type 2 patients seen in outpatient setting. Rev Dor. 2014;15(4):256-9

28. Kim SS, Won JC, Kwon HS, Kim CH, Lee JH, Park TS, et al. Prevalence and clinical implications of painful diabetic peripheral neuropathy in type 2 diabetes: Results from a nationwide hospital-based study of diabetic neuropathy in Korea. Diabetes Res Clin Pract. 2014; 103(3):522-9.

29. Chiang SS, Lee CL, Liu HC, Wang JS, Lee IT, Song YM, et al. Physical activity and albuminuria were associated with painful diabetic polyneuropathy in type 2 diabetes in an ethnic Chinese population. Clin Chim Acta. 2016;462:55-9.

30. Halawa MR, Karawagh A, Zeidan A, Mahmoud AE, Sakr M, Hegazy A. Prevalence of painful diabetic peripheral neuropathy among patients suffering from diabetes mellitus in Saudi Arabia. Curr Med Res Opin. 2010;26(2):337-43.

31. Sociedade Brasileira de Diabetes. Diretrizes da Sociedade Brasileira de Diabetes (2015-2016). São Paulo (SP): AC Farmacêutica; 2016.

32. Posso IP, Palmeira CC, Vieira EB. Epidemiologia da dor neuropática. Rev Dor. 2016;17(Suppl 1):S11-4.

33. Dobrota VD, Hrabac P, Skegro D, Smiljanic R, Dobrota S, Prkacin I, et al. The impact of neuropathic pain and other comorbidities on the quality of life in patients with diabetes. Health Qual Life Outcomes. 2014;12(1):1-8.

34. Veves A, Backonja, M, Malik RA. Painful diabetic neuropathy: epidemiology, natural history, early diagnosis, and treatment options. Pain Med. 2008;9(6):660-74.

35. Abbott CA, Malik RA, Ross ER, Kulkarni J, Boulton AJM, Prevalence and characteristics of painful diabetic neuropathy in a large community-based. Diabetic population in the U.K. Diabetes Care. 2011;34(10):2220-4.

36. Hoffman Dl, Sadosky A, Alvir J. Cross-national burden of painful diabetic peripheral neuropathy in Asia, Latin America, and the Middle East. Pain Pract. 2009;9(1):35-42.

37. Bouhassira D, Letanoux M, Hartemann A. Chronic pain with neuropathic characteristics in diabetic patients: a French cross-sectional study. PLoS One. 2013;8(9):E74195.

38. Goldenberg P, Schenkman S, Franco LJ. Prevalência de diabetes mellitus: diferenças de gênero e igualdade entre os sexos. Rev Bras Epidemiol. 2003;6(1):18-28.

39. Schmader KE. Epidemiology and impact on quality of life of postherpetic neuralgia and painful diabetic neuropathy. Clin J Pain. 2002;18(6):350-4.

40. Cheng YJ, Imperatore G, Geiss LS, Wang J, Saydah SH, Cowie CC, et al. Secular changes in the age-specific prevalence of diabetes among U.S. adults: 1988-2010. Diabetes Care. 2013;36(9):2690-6.

41. Silva TS. Caracterizaçāo e identificação de dor associada à polineuropatia diabética distal em atençăo primária. 2013. 53 f. TCC (Graduaçáo).

42. Instituto Brasileiro de Geografia e Estatística. Síntese de indicadores sociais: uma análise das condiçốes de vida da população brasileira; 2010.

43. Fernandes LC, Bertoldi AD, Barros AJ. [Health servisse use in population covered by the Estratégia de Saúde da Família (Family Health Strategy)]. Rev Saude Publica. 2009; 43(4):595-603. English, Portuguese.

44. Freitas LR, Garcia LP. Evolução da prevalência do diabetes e deste associado à hipertensẫo arterial no Brasil: análise da Pesquisa Nacional por Amostra de Domicílios, 1998, 2003 e 2008. Epidemiol Serv Saúde. 2012;21(1):7-19.

45. Erbas T, Ertas M, Yucel A, Keskinaslan A, Senocak M; TURNEP Study Group. Prevalence of peripheral neuropathy and painful peripheral neuropathy in Turkish diabetic patients. J Clin Neurophysiol. 2011;28(1):51-5.

46. Lopes JM. Dores Neuropáticas. Porto, Portugal: Medesign; 2007.

47. Goren A, Gross HJ, Fujii RK, Pandey A, Mould-Quevedo J. Prevalence of pain awareness, treatment, and associated health outcomes across different conditions in Brazil. Rev Dor. 2012;13(4):308-19.

48. Peacock S, Patel S. Cultural influences on pain. Br J Pain. 2008;1(2):6-9.

49. Costa MC. Dor neuropática. In: Alves Neto O et al. (org.). Dor: Princípios e prática. Porto Alegre: Artmed; 2009. 495-509p.

50. Soyannwo OA. Improved neuropathic pain treatment in developing countries-a critical review of WHO essential list. Pain. 2015;156(5):763-4.

51. Kamerman PR, Wadley AL, Davis KD, Hietaharju A, Jain P, Kopf A, et al. World Health Organization (WHO) essential medicines lists. Pain. 2015;156(5):793-7. 